\title{
Modification of Gamma Radiation and 4-Nitroquinoline 1-Oxide Induced Genotoxicity by Tumour Promoter Iodoacetate
}

\author{
K. B. Anjaria*, N. N. Bhat, K.B. Shirsath and Sreedevi B. \\ Radiological Physics and Advisory Division, Bhabha Atomic Research Centre, Trombay, \\ Mumbai 400 0085, Maharashtra, India
}

KEYWORDS Iodoacetate; tumour promoter; gamma radiation; 4-nitroquinoline 1-oxide; genotoxicity; yeast

\begin{abstract}
Modifying effects of tumour promoter Iodoacetic Acid - sodium salt (IA) was studied on ${ }^{60}$ Co gamma radiation and 4-Nitroquinoline 1-oxide (4-NQO) induced recombination (gene conversion), back mutation and aberrant colony formation (ACF) using eukaryotic model system, yeast. Cells were exposed to 0-400 Gy of radiation or were treated with $0.15-1.5 \mathrm{mM} 4-\mathrm{NQO}$ and grown on the media containing $0-200 \mu \mathrm{g} \mathrm{IA} / \mathrm{ml}$. The results indicated that IA reduced the frequencies of spontaneous; gamma radiation as well as 4-NQO induced back mutation and ACF significantly. Further, it had no effect on spontaneous, radiation or 4-NQO induced recombination (gene conversion) frequency. These observations suggest that IA does not act like other tumour promoters, which enhance the frequency of genetic events induced by carcinogens in vitro.
\end{abstract}

\section{INTRODUCTION}

A large amount of information is available in literature indicating that the action of one agent can be altered by another agent, leading to enhancement, reduction or additivity, following combined exposures (UNSCEAR 1999). Chemical agents, which act as tumour promoters, or those, which inhibit error-free repair pathways, may enhance the effects of a mutagenic/carcinogenic agent (Anjaria and Rao 2001, 2004). Antimutagenic/anticarcinogenic agents, or agents which suppress error-prone repair, may reduce the mutagenic effects of a physical or chemical agent in the combined treatments (Anjaria and Rao 2001).

Carcinogenesis is suggested to be a two-stage process: initiation and promotion. Initiation is generally induced by DNA damaging agents like radiation or chemicals and is suggested to be an irreversible event, whereas promotion is suggested to be a reversible process resulting from repetitive exposures of tumour promoting agents subsequent to the exposure to initiating agents (Yamasaki, 1980). It has been reported that tumour-promoting agents potentiate a number of genetic events induced by initiating agents (e.g. gene mutations, sister chromatid exchanges (SCE), gene conversion) in yeast and mammalian cells in vitro (Trosko et al. 1977; Gentil et al. 1980;

*Corresponding author: K. B. Anjaria

Telephone: +91-022-25593968

Fax: +91-22- 25519209 .

E-mail: k_anjaria@hotmail.com
Kunz et al. 1980b; Fahrig 1984; Anjaria and Rao 2001)

IA is reported to be a tumour promoter of moderate potency (Connell and Duncan 1981) and although to the best of our knowledge, tumour promoting ability of IA in animals has not been reported, a large number of studies have reported various aspects of its tumour promoting activities (Connell and Duncan 1981; Kinsella 1982). In this paper, we have reported the modifying effects of tumour promoter IA on genotoxic effects induced by gamma radiation or 4-NQO in a eukaryotic model system, diploid yeast.

\section{MATERIALS AND METHODS}

2.1 Strain: Diploid strain of yeast Saccharomyces cerevisiae D7 was used for the present study. The genotype of the strain is as follows:

$$
\frac{a}{\alpha} \frac{\text { ade } 2-40}{\text { ade } 2-119}, \frac{\operatorname{trp} 5-12}{\operatorname{trp} 5-27}, \frac{i l v 1-92}{i l v 1-92}
$$

The strain was used to detect the induction of gene conversion at trp locus, and reverse mutation at ilv locus. The details of the media and procedures have been described elsewhere (Zimmermann 1973, 1977; Zimmermann et al. 1975)

2.2 Chemicals: 4-NQO was purchased from K \& K Laboratories, New York, USA. IA (purchased from Sigma) was dissolved in distilled water, sterilized by filtering through Millipore filter (pore size $0.45 \mu \mathrm{m}$ ) and added to autoclaved media just before pouring in Petri dishes.

2.3 Detection of Genetic End-points: Gene 
conversion at tryptophan locus results in the conversion of cells from tryptophan auxotrophy to prototrophy, which is detected by the appearance of colonies on tryptophan omission medium. Reverse mutation is detected similarly by the appearance of prototrophic colonies on isoleucine omission medium. ACF (Aberrant Colony Formation) was observed and scored on synthetic complete media as described by Zimmermann et al. (Zimmermann 1973, 1977; Zimmermann et al. 1975)

2.4 Significance of Genetic End-points: Recombination is suggested to be involved in carcinogenesis, teratogenesis, tumour promotion and expression of deleterious genes following recombination may also result in heritable changes (Zimmermann, 1966; Kinsella and Radman, 1978; Kunz et al. 1980a,b). Homologous genes of RAD52 epistasis group which are involved in recombination have been identified in fission yeast (Ostermann et al. 1993), Drosophila melanogaster (Akaboshi 1994), chicken (Bezzubova et al. 1993), mouse and human beings (Shinohara et al. 1993; Morita et al. 1993). This indicates that the recombinational repair pathway is conserved throughout evolution (Sung et al. 2000; Cromie et al. 2001). Furthermore, homo-logous genes HsRAD52 controlling recombi-national pathways have been identified in human cells (Thomson 1996; Dudas and Chovanec 2004). Furthermore, the generation of homozygous HR (homologous recombination) knockout mice (Lim and Hasty 1996; Tsuzuki et al. 1996; Essers et al. 1997; Rijkers et al. 1998; Luo et al. 1999; Shu et al. 1999; Deans et al. 2000; Pitman and Schimenti 2000) and embryonic stem cells has also highlighted the importance of the HR pathway in Double Strand Break repair in higher eukaryotes (Lim and Hasty 1996; Tsuzuki et al. 1996; Luo et al. 1999; Deans et al. 2000). In addition the breast cancer susceptibility proteins Brca 1 and Brca 2, seem to be directly involved in the homologous recombination process in mammalian cells (Thomson and Schild 1999, 2001; Morrison and Takeda 2000; van den Bosch et al. 2002)

Mutation is a very well studied end-point and a high correlation is found between carcinogenicity and mutagenicity (Miller and Miller 1971; McCann et al. 1975, 1976). Formation of aberrant colonies in yeast can be due to mitotic gene conversion, point mutation, chromosome deletion or aneuploidy induced by a mutagen. It has been suggested that aberrant mitotic segregation events like mitotic recombination, non-disjunction and other chromosome events might be involved in tumour promotion (Kinsella and Radman 1978). These genetic events occurring in eukaryotic model system diploid yeast are important as similar events may occur in human beings.

2.5 Gamma Irradiation: Stationary phase cells were washed three times by centrifugation and resuspended at a titre of $10^{7}$ cells per $\mathrm{ml}$ in potassium phosphate buffer $(0.1 \mathrm{M}, \mathrm{pH} 7.0)$. The suspension was distributed in $5 \mathrm{ml}$ aliquots in irradiation vials which were exposed to graded doses of gamma radiation in the dose range of $25-400$ Gy in the ${ }^{60} \mathrm{Co}$ Gamma Chamber 900 (supplied by BRIT, India) having a dose rate of $50 \mathrm{~Gy} / \mathrm{min}$. The samples were agitated vigorously in a vortex mixture to aerate them properly just before irradiation. They were maintained in icebath before and after irradiation till they were plated to arrest the metabolic activities in the cells. Irradiated cell suspensions were plated on isoleucine omission medium to detect reverse mutation, tryptophan omission medium to detect gene conversion and synthetic complete medium to detect ACF and survival. Same irradiated cell suspensions were also plated on all the three media containing different concentrations of IA to study its modifying effects.

2.6 Treatment with 4-NQO: The stock solution of 4-NQO was prepared freshly by dissolving in DMSO. It was diluted to get the required concentration in potassium phosphate buffer $(0.1 \mathrm{M}, \mathrm{pH} 7.0)$. The stationary phase cells were washed three times by centrifugation and resuspended in buffer at a cell titre of $5 \times 10^{7}$ cells/ $\mathrm{ml}$. For the treatment, generally $1 \mathrm{ml}$ of cell suspension, required volume of diluted 4-NQO solution and buffer were mixed to get $10 \mathrm{ml}$ of treatment mixture such that the final cell titre in the treatment mixture was $10^{7} \mathrm{cells} / \mathrm{ml}$ and the 4NQO concentrations were $0.15-1.5 \mu \mathrm{M}$. The treatments were carried out in a shaker water-bath at $30^{\circ} \mathrm{C}$ for $1 \mathrm{~h}$ in dark. At the end of $1 \mathrm{~h}, 5 \mathrm{ml}$ aliquots of treatment mixtures were withdrawn and filtered through Millipore filter (pore size $0.45 \mu \mathrm{m}$ ). The cells were washed three times with buffer and the filter paper with the cells was then resuspended in sterile water to get the cell titre of $10^{7}$ cells/ml. Suitable dilutions of these cell suspensions were plated on isoleucine and tryptophan omission plates to score back mutation and 
gene conversion respectively and synthetic complete medium to score ACF and survival. The cell suspensions were also plated on these media containing $0-200 \mu \mathrm{g} / \mathrm{ml}$ IA. The plates were incubated at $30^{\circ} \mathrm{C}$ in an incubator. The colonies were scored after 3 days for gene conversion and survival; and after 5 days for back mutation and ACF.

\section{RESULTS}

In all the experiments, doses up to $100 \mathrm{~Gy}$ of gamma radiation and $1 \mu \mathrm{M}$ of $4-\mathrm{NQO}$ did not induce any cell killing either independently or following combined treatments. However, survival level following $400 \mathrm{~Gy}$ of radiation was $33 \%$ and following $1.5 \mu \mathrm{M} 4-\mathrm{NQO}$ treatment was $56 \%$. IA did not induce significant killing up to $100 \mu \mathrm{g} / \mathrm{ml}$ of medium.

3.1 Effect of IA on Back Mutation Frequency: The results indicate that IA reduced spontaneous back mutation frequency significantly and consistently (Tables $1 \mathrm{a}, 1 \mathrm{~b}$ and $2 \mathrm{a}, 2 \mathrm{~b}$ ). It should be noted that since different batches of D7 yeast cultures were used in independent experiments, the spontaneous frequencies of back mutations varied from $26 / 10^{7}$ survivors in Table 1 to 56/10 ${ }^{7}$ survivors in Table 2. However, the conclusion based on these experiments remains the same as the results were consistent

Table 1: Effect of IA on gamma radiation induced back mutation in strain D7

\begin{tabular}{|c|c|c|c|c|c|c|c|c|c|}
\hline \multirow{2}{*}{\multicolumn{2}{|c|}{$\begin{array}{l}\text { Gamma dose } \\
\text { (Gy) } \\
\text { (a) - }\end{array}$}} & \multirow{2}{*}{$\frac{I A \mu g / m l}{-}$} & \multicolumn{4}{|c|}{$\begin{array}{c}\text { Revertants } / 10^{7} \\
\text { Survivors } \\
\left(R / 10^{7} s\right)^{1} \\
\end{array}$} & \multicolumn{3}{|c|}{$\begin{array}{c}\text { Ratio of } \\
R / 10^{7} s \\
O / E^{2} \\
\end{array}$} \\
\hline & & & 26 & & 7 & $(68)$ & & - & \\
\hline & - & 2.5 & 11 & \pm & 3 & $(30)$ & 0.433 & \pm & $0.048^{\mathrm{a}}$ \\
\hline & - & 7.5 & 3 & \pm & 0 & (7) & 0.0983 & \pm & $0.02^{\mathrm{a}}$ \\
\hline & - & 10 & 3 & \pm & 1 & (7) & 0.094 & \pm & $0.043^{\mathrm{a}}$ \\
\hline & 25 & - & 141 & \pm & 25 & (367) & & - & \\
\hline & 25 & 2.5 & 78 & \pm & 14 & (198) & 0.574 & \pm & $0.167^{\mathrm{b}}$ \\
\hline & 25 & 7.5 & 43 & & 6 & (138) & 0.394 & \pm & $0.11^{\mathrm{a}}$ \\
\hline & 25 & 10 & 38 & \pm & 1 & (118) & 0.267 & \pm & $0.034^{\mathrm{a}}$ \\
\hline & 50 & - & 224 & \pm & 54 & (597) & & - & \\
\hline & 50 & 2.5 & 137 & \pm & 20 & (353) & 0.665 & \pm & 0.236 \\
\hline & 50 & 7.5 & 100 & \pm & 24 & (256) & 0.497 & \pm & $0.212^{\mathrm{b}}$ \\
\hline & 50 & 10 & 79 & \pm & 14 & (204) & 0.381 & \pm & $0.145^{\mathrm{a}}$ \\
\hline & 75 & - & 293 & & 98 & (793) & & - & \\
\hline & 75 & 2.5 & 177 & \pm & 8 & (464) & 0.68 & \pm & 0.237 \\
\hline & 75 & 7.5 & 130 & \pm & 7 & (340) & 0.493 & \pm & $0.154^{\mathrm{a}}$ \\
\hline & 75 & 10 & 92 & \pm & 9 & (243) & 0.338 & \pm & $0.075^{\mathrm{a}}$ \\
\hline & 100 & - & 358 & \pm & 90 & (940) & & - & \\
\hline & 100 & 2.5 & 215 & \pm & 48 & (547) & 0.708 & \pm & $0.129^{b}$ \\
\hline & 100 & 7.5 & 202 & \pm & 36 & $(520)$ & 0.597 & \pm & $0.152^{\mathrm{c}}$ \\
\hline & 100 & 10 & 142 & \pm & 46 & (364) & 0.407 & \pm & $0.144^{\mathrm{a}}$ \\
\hline \multirow[t]{10}{*}{ (b) } & - & - & 23 & \pm & 15 & $(76)$ & & - & \\
\hline & - & 15 & 1.67 & \pm & 2.4 & (3) & 0.037 & \pm & $0.05^{\mathrm{a}}$ \\
\hline & - & 50 & 0.33 & $\overline{ \pm}$ & 0.47 & 7 (1) & 0.0067 & \pm & $0.009^{\mathrm{a}}$ \\
\hline & - & 100 & & & & 0 & & & 0 \\
\hline & - & 200 & & & & 0 & & & 0 \\
\hline & 100 & 0 & 240 & \pm & 49 & $(641)$ & & - & \\
\hline & 100 & 15 & 76 & \pm & 17 & (228) & 0.33 & \pm & $0.1^{\mathrm{a}}$ \\
\hline & 100 & 50 & 18 & \pm & 9 & (46) & 0.083 & \pm & $0.058^{\mathrm{a}}$ \\
\hline & 100 & 100 & 7 & \pm & 8 & (22) & 0.04 & \pm & $0.05^{\mathrm{a}}$ \\
\hline & 100 & 200 & & & & 0 & & & 0 \\
\hline
\end{tabular}

1 Values represent mean of 3 experiments \pm s.d.

2 Mean ratio of experimentally observed R/107s values divided by expected values \pm s.d. (Expected values in each set of data are values which are obtained in the absence of IA)

In each set of data, values of $\mathrm{R} / 10^{7} \mathrm{~s}$ obtained in the presence of different concentrations of IA (observed values) are significantly lower as compared to those observed without IA (expected values) at the confidence levels given below.

a. $\mathrm{p}<0.0027$, b. p <0.0455, c. p <0.01

* Values in the parentheses represent actual colonies counted. 
and identical in both the sets of experiments, showing significant reduction in spontaneous frequencies with IA, irrespective of the variation in spontaneous back mutation frequencies in these two sets of experiments. Further, the spontaneous back mutation frequency was found to reduce to approximately $40 \%$ at $2.5 \mu \mathrm{g} /$ $\mathrm{ml}, 9 \%$ at $7.5 \mu \mathrm{g} / \mathrm{ml}$ and $6 \%$ at $10 \mu \mathrm{g} / \mathrm{ml}$ of IA (Table 1a), whereas Table 2 a shows that spontaneous back mutation frequency reduced approximately to $47 \%$ at $2 \mu \mathrm{g} / \mathrm{ml}, 55 \%$ at $4 \mu \mathrm{g} / \mathrm{ml}$ and $49 \%$ at $6 \mu \mathrm{g} / \mathrm{ml}$. This indicates that although the trend of reduction was consistently seen in both sets of experiments, the extent of reduction is not dependent on the concentration of IA. Significant reduction in back mutation frequency was also observed when cells exposed to gamma radiation were plated on media containing different concentrations of IA. The reduction was found to occur for all the dose points (25-100Gy) when IA concentration was increased from 2.5 to $10 \mu \mathrm{g} / \mathrm{ml}$ and for $100 \mathrm{~Gy}$ at IA concentration in the range of $15-200 \mu \mathrm{g} / \mathrm{ml}$ (Table $1 \mathrm{a}, 1 \mathrm{~b}$ ). In each set of data, values of $\mathrm{R} / 10^{7} \mathrm{~s}$ obtained in the presence of different concentrations of IA (termed as Observed Values) are significantly lower as compared to those observed without IA (termed as Expected Values) at the confidence levels given in the footnote of Table 1

Table 2 shows the effect of IA on 4-NQO induced back mutation frequency. The results indicate that IA also reduced the 4-NQO induced back mutation frequency in a dose dependent manner. The reduction was statistically significant only with $6 \mu \mathrm{g} / \mathrm{ml}$ of IA (Table $2 \mathrm{a}$ ) and for $0.5 \mu \mathrm{M} 4-\mathrm{NQO}$ for IA concentration in the range of $50-200 \mu \mathrm{g} / \mathrm{ml}$ (Table $2 \mathrm{~b}$ ). Since $4-N Q O$ requires metabolic activation for the induction of genotoxic effects, the D7 yeast cultures belonging to different batches show different

Table 2: Effect of IA on 4-NQO induced back mutation in strain D7

\begin{tabular}{|c|c|c|c|c|c|c|c|}
\hline \multirow{2}{*}{$\begin{array}{l}\text { 4-NQO( } \mu M) \\
\text { (a) - }\end{array}$} & \multirow{2}{*}{$\frac{I A \mu g / m l}{-}$} & \multicolumn{3}{|c|}{$\begin{array}{c}\text { Revertants } / 10^{7} \\
\text { survivors }^{*} \\
\left(\mathrm{R} / 10^{7} \mathrm{~s}\right)^{1}\end{array}$} & \multicolumn{3}{|c|}{$\begin{array}{c}\text { Ratio of } \\
R / 10^{7} s \\
(O / E)^{2}\end{array}$} \\
\hline & & 56 & \pm 47 & (38) & & - & \\
\hline- & 2 & 25 & \pm 18 & (19) & 0.47 & \pm & $0.06^{\mathrm{a}}$ \\
\hline - & 4 & 27 & \pm 20 & (28) & 0.55 & \pm & $0.09^{a}$ \\
\hline - & 6 & 19 & \pm 6 & (23) & 0.49 & \pm & $0.22^{\mathrm{a}}$ \\
\hline 0.15 & - & 101 & \pm 23 & (139) & & - & \\
\hline 0.15 & 2 & 88 & \pm 36 & (99) & 0.85 & \pm & 0.22 \\
\hline 0.15 & 4 & 70 & \pm 28 & $(76)$ & 0.67 & \pm & $0.16^{\mathrm{b}}$ \\
\hline 0.15 & 6 & 52 & \pm 22 & (59) & 0.53 & \pm & $0.21^{\mathrm{b}}$ \\
\hline 0.30 & - & 207 & \pm 79 & (327) & & - & \\
\hline 0.30 & 2 & 196 & \pm 53 & (390) & 1.12 & \pm & 0.42 \\
\hline 0.30 & 4 & 171 & \pm 72 & (297) & 0.83 & \pm & 0.13 \\
\hline 0.30 & 6 & 139 & \pm 53 & (201) & 0.67 & \pm & $0.09^{a}$ \\
\hline 0.50 & - & 546 & \pm 235 & $(827)$ & & - & \\
\hline 0.50 & 2 & 457 & \pm 45 & $(753)$ & 0.87 & \pm & 0.16 \\
\hline 0.50 & 4 & 394 & \pm 162 & (666) & 0.75 & \pm & 0.18 \\
\hline 0.50 & 6 & 357 & \pm 145 & $(482)$ & 0.60 & \pm & $0.04^{\mathrm{a}}$ \\
\hline (b) - & - & 27 & \pm 18 & $(57)$ & & - & \\
\hline- & 15 & 2.5 & $\pm \quad 2.5$ & (3) & 0.055 & \pm & $0.055^{\mathrm{a}}$ \\
\hline - & 50 & 0.5 & 0.5 & (1) & 0.01 & \pm & $0.01^{\mathrm{a}}$ \\
\hline - & 100 & & & 0 & & & 0 \\
\hline - & 200 & & & 0 & & & 0 \\
\hline 0.50 & - & 262 & \pm 117 & $(527)$ & & - & \\
\hline 0.50 & 15 & 222 & \pm 92 & (432) & 0.58 & \pm & 0.32 \\
\hline 0.50 & 50 & 62 & \pm 60 & (105) & 0.055 & \pm & $0.045^{\mathrm{a}}$ \\
\hline 0.50 & 100 & 1.5 & \pm 1.5 & & 0.01 & \pm & $0.01^{\mathrm{a}}$ \\
\hline 0.50 & 200 & & & 0 & & & 0 \\
\hline
\end{tabular}

1.Values represent mean of 3 experiments \pm s.d.

2.Mean ratio of experimentally observed R/107 s values divided by expected values \pm s.d. (Expected values in each set of data are values which are obtained in the absence of IA)

In each set of data, values of $\mathrm{R} / 10^{7} \mathrm{~s}$ obtained in the presence of different concentrations of IA (observed values) are significantly lower as compared to those observed without IA (expected values) at the confidence levels given below a. $\mathrm{p}<0.0027$, b. $\mathrm{p}<0.0455$

* Values in the parentheses represent actual colonies counted 
levels of genetic activity depending upon the metabolic status in different cultures which is reflected as back mutation frequencies of $546 \mathrm{R} /$ $10^{7}$ survivors with $0.5 \mu \mathrm{M} 4-\mathrm{NQO}$ in Table $2 \mathrm{a}$ and half the value of $262 \mathrm{R} / 10^{7}$ survivors induced with the same concentration of 4-NQO as shown in Table 2b. However, the important factor to be noted here is that in spite of these variations, the trend showing reduction in 4-NQO induced back mutation is consistent and statistically significant.

In one out of two experiments carried out, IA at some of the concentrations completely inhibited spontaneous, gamma radiation induced and 4-NQO induced back mutation whereas sometimes in the second experiment, colonies observed in the presence of IA was either 0 or very few. In the presence of the highest concentration of IA $(200 \mu \mathrm{g} / \mathrm{ml})$, the percent survival was $84 \%$ for control, $83 \%$ for $0.5 \mu \mathrm{M} 4$ NQO treated cells and $80 \%$ for cells irradiated to $100 \mathrm{~Gy}$ of gamma radiation indicating that inhibition of back mutation by IA was not due to its toxicity. In this case also, in each set of data, values of $R / 10^{7} \mathrm{~s}$ obtained in the presence of different concentrations of IA (observed values) are significantly lower as compared to those observed without IA (expected values) at the confidence levels given in the footnote of Table 2.

3.2 Effect of IA on ACF: Table 3 shows the effect of IA on radiation and 4-NQO induced ACF. IA (50 or $100 \mu \mathrm{g} / \mathrm{ml}$ ) alone had no effect on spontaneous frequency of ACF. Radiation alone (400 Gy) induced $284 \mathrm{ACF} / 10^{4}$ survivors, which reduced to $0 / 10^{4}$ survivors in the presence of 50 $\mu \mathrm{g} / \mathrm{ml}$ of IA. 4-NQO (1.5 $\mu \mathrm{M}, 1 \mathrm{~h})$ alone induced
$97 \mathrm{ACF} / 10^{4}$ survivors. Even though it increased to $128 / 10^{4}$ survivors in the presence of $50 \mu \mathrm{g} / \mathrm{ml}$ of IA, the increase was not statistically significant. 4-NQO $(1 \mu \mathrm{M}, 1 \mathrm{~h})$ induced $39 \mathrm{ACF} / 10^{4}$ survivors but even in this case, it decreased to $0 /$ $10^{4}$ survivors in the presence of $100 \mu \mathrm{g} / \mathrm{ml}$ of IA, indicating that $\mathrm{IA}$ reduces the frequency of radiation as well as 4-NQO induced ACF in the same way as back mutation. Mitotic crossing over (MCO) (reciprocal recombination) was not induced by gamma radiation or 4-NQO either alone nor was potentiated in the presence of IA at these doses in the above experiments.

3.3 Effect of IA on Gene Conversion Frequency: Table 4 shows the effect of IA (2.5$100 \mu \mathrm{g} / \mathrm{ml}$ ) on spontaneous and radiation induced gene conversion frequency. The results indicate that IA had no effect on gamma radiation induced gene conversion frequency.

Table 5 shows the effect of IA $(2-100 \mu \mathrm{g} / \mathrm{ml})$ on spontaneous as well as 4-NQO induced gene conversion frequency. The results indicate that presence of IA in the growth media did not alter spontaneous or 4-NQO induced gene conversion frequency.

\section{DISCUSSION}

Carcinogen-induced mutation can be recessive and heterozygous (Harris et al. 1968; Stanbridge 1976; Gateff 1978). The mechanism by which a heterozygous recessive mutant allele is expressed can be either gene mutation, loss of a wild type allele through deletion or monosomy or a recombinational process. Simultaneous investigation of these genetic alterations in mammalian systems is impossible. The only

Table 3: Effect of IA on radiation and 4 - NQO induced ACF in strain D7

\begin{tabular}{lrrr}
\hline Treatment & $I A \mu g / m l$ & $\%$ Survival & $A C F / 10^{4} S^{*}$ \\
\hline Control & - & $100 \%$ & $0(0 / 8895)$ \\
Control & +50 & $98 \%$ & $3(2 / 6423)$ \\
Control & +100 & $94 \%$ & $0(0 / 2573)$ \\
400 Gy & - & $33 \%$ & $284(205 / 7226)$ \\
400 Gy & +50 & $36 \%$ & $0^{\mathrm{a}}(0 / 7969)$ \\
$1.5 \mu \mathrm{M} 4 \mathrm{NQO}, 1 \mathrm{~h}$ & - & $56 \%$ & $97\left(69-125 / 10^{4} \mathrm{~s}\right)^{\mathrm{b}}(45 / 4643)$ \\
$1.5 \mu \mathrm{M} 4 \mathrm{NQO}, 1 \mathrm{~h}$ & +50 & $53 \%$ & $128\left(94-162 / 10^{4} \mathrm{~s}\right)^{\mathrm{b}}(56 / 4383)$ \\
$1 \mu \mathrm{M} 4$ NQO, 1h & - & $100 \%$ & $39(35 / 8959)$ \\
$1 \mu \mathrm{M} 4 \mathrm{NQO}, 1 \mathrm{~h}$ & +100 & $93 \%$ & $0^{\mathrm{c}(0 / 6816)}$ \\
\hline
\end{tabular}

* The numbers in parenthesis indicate actual colonies counted.

a Reduction in ACF / $10^{4} \mathrm{~S}$ in presence of $50 \mu \mathrm{g} / \mathrm{ml} \mathrm{IA}$ is statistically significant as compared to $284 \mathrm{ACF} / 10^{4} \mathrm{~S}$ observed with $400 \mathrm{~Gy}$ radiation in the absence of IA.

b Values indicate $95 \%$ confidence range.

c Reduction in ACF / $10^{4} \mathrm{~S}$ in presence of $100 \mu \mathrm{g} / \mathrm{ml} \mathrm{IA}$ is statistically significant as compared to $39 \mathrm{ACF} / 10^{4} \mathrm{~S}$ observed with $1 \mu \mathrm{M} 4-\mathrm{NQO}, 1 \mathrm{~h}$, in the absence of IA. 
Table 4: Effect of IA on gamma radiation induced gene conversion in strain $D 7$

\begin{tabular}{|c|c|c|c|c|c|c|c|c|}
\hline $\begin{array}{l}\text { Gamma } \\
\text { Dose } \\
(G y)\end{array}$ & $\begin{array}{c}I A \\
\mu g / m l\end{array}$ & & & $\begin{array}{l}\text { ertan } \\
\text { rvivo } \\
10^{6} s\end{array}$ & $\begin{array}{l}\text { nts/ } \\
\text { ors }^{*}\end{array}$ & & D/E & \\
\hline - & - & 9 & & 5 & (37) & & - & \\
\hline - & 2.5 & 6 & & 0 & $(10)$ & 0.67 & \pm & 0.00 \\
\hline - & 7.5 & 7 & & 5 & (12) & 0.78 & \pm & 0.29 \\
\hline- & 10 & 9 & \pm & 2 & (15) & 1.00 & \pm & 0.16 \\
\hline - & 15 & 10 & \pm & 3 & (18) & 1.11 & \pm & 0.56 \\
\hline - & 50 & 10 & \pm & 1 & (18) & 1.11 & \pm & 0.13 \\
\hline - & 100 & 9 & $=$ & 3 & (17) & 1.00 & \pm & 0.25 \\
\hline 25 & - & 124 & \pm & 8 & (203) & & - & \\
\hline 25 & 2.5 & 122 & \pm & 3 & $(208)$ & 1.03 & \pm & 0.04 \\
\hline 25 & 7.5 & 131 & \pm & 9 & (213) & 1.06 & \pm & 0.01 \\
\hline 25 & 10 & 137 & 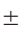 & 28 & $(223)$ & 1.1 & \pm & 0.16 \\
\hline 50 & - & 239 & \pm & 2 & (391) & & - & \\
\hline 50 & 2.5 & 228 & \pm & 3 & (374) & 0.96 & \pm & 0.01 \\
\hline 50 & 7.5 & 228 & - & 13 & (373) & 0.96 & \pm & 0.06 \\
\hline 50 & 10 & 225 & \pm & 10 & (368) & 0.95 & \pm & 0.05 \\
\hline 75 & - & 289 & \pm & & $(470)$ & & - & \\
\hline 75 & 2.5 & 275 & 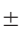 & 28 & $(452)$ & 0.96 & \pm & 0.07 \\
\hline 75 & 7.5 & 280 & - & 43 & (462) & 0.98 & \pm & 0.13 \\
\hline 75 & 10 & 297 & \pm & 20 & (489) & 1.05 & \pm & 0.06 \\
\hline 100 & - & 425 & \pm & 45 & (695) & & 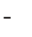 & \\
\hline 100 & 2.5 & 409 & \pm & & (671) & 0.98 & \pm & 0.12 \\
\hline 100 & 7.5 & 406 & \pm & & (665) & 0.97 & \pm & 0.10 \\
\hline 100 & 10 & 446 & & 53 & (729) & 1.05 & \pm & 0.02 \\
\hline 100 & - & 515 & & 144 & (916) & & . & \\
\hline 100 & 15 & 487 & & 171 & (943) & 0.93 & \pm & 0.08 \\
\hline 100 & 50 & 469 & & 161 & (881) & 0.91 & \pm & 0.08 \\
\hline 100 & 100 & 331 & \pm & 73 & (611) & 0.74 & \pm & 0.35 \\
\hline
\end{tabular}

1 Values represent mean of 2 experiments \pm s.d.

2 Mean ratio of experimentally observed $\mathrm{C} / 10^{6} \mathrm{~s}$ values divided by expected values \pm s.d. (Expected values in each set of data are values which are obtained in the absence of IA)

* Values in the parentheses indicate actual colonies counted

suitable in vivo system is the spot test (Russell and Major 1957; Fahrig 1975, 1978), which presumably involves all the alterations mentioned before but allows distinction only between induced forward mutations (including small deletions) and reciprocal recombination (mitotic crossing over). In microorganisms, model systems suitable for this purpose are diploid yeast strains, which allow screening for both reciprocal and non-reciprocal recombination as well as for mutation and ACF (Fahrig 1984).

It has been observed in a number of in vitro test systems that tumour promoters potentiate the genotoxic effects induced by carcinogens in vitro. Trosko et al. (1977) have demonstrated that the tumour promoter 12-O-tetradecanoylphorbol13-acetate (TPA) enhanced UV induced mutations in mammalian cells and also chemical carcinogens induced mutations in Salmonella
Table 5: Effect of IA on 4-nqo induced gene conversion in strain $\mathrm{D} 7$

\begin{tabular}{|c|c|c|c|c|c|c|c|c|}
\hline \multirow{2}{*}{$\begin{array}{c}\text { 4-NQO } \\
(\mu M) \\
-\end{array}$} & \multirow{2}{*}{$\begin{array}{l}I A \mu g / \\
m l\end{array}$} & \multicolumn{4}{|c|}{$\begin{array}{l}\text { Convertants/ } \\
10^{6} \text { Survivors } \\
\left(C / 10^{6}\right)^{1}\end{array}$} & \multicolumn{3}{|c|}{$\begin{array}{l}\text { Ratio of } \\
C / 10^{6} \mathrm{~s} \\
(\mathrm{O} / \mathrm{E})^{2}\end{array}$} \\
\hline & & 9 & \pm & 5 & (37) & & - & \\
\hline- & 2 & 11 & \pm & 7 & (17) & 0.96 & \pm & 0.41 \\
\hline- & 4 & 12 & \pm & 7 & (16) & 1.04 & \pm & 0.33 \\
\hline- & 6 & 12 & \pm & 8 & (20) & 1.13 & \pm & 0.52 \\
\hline- & 15 & 10 & \pm & 3 & (18) & 1.11 & \pm & 0.56 \\
\hline - & 50 & 10 & \pm & 1 & (18) & 1.11 & \pm & 0.13 \\
\hline- & 100 & 9 & \pm & 3 & (17) & 1.00 & \pm & 0.25 \\
\hline 0.15 & . & 56 & \pm & 28 & (90) & & - & \\
\hline 0.15 & 2 & 60 & \pm & 9 & (103) & 1.08 & \pm & 0.15 \\
\hline 0.15 & 4 & 52 & \pm & 7 & $(82)$ & 0.88 & \pm & 0.01 \\
\hline 0.15 & 6 & 58 & \pm & 18 & ) & 1.15 & \pm & 0.32 \\
\hline 0.30 & - & 187 & \pm & 67 & (372) & & - & \\
\hline 0.30 & 2 & 179 & \pm & 54 & (355) & 0.99 & \pm & 0.10 \\
\hline 0.30 & 4 & 187 & \pm & 46 & (343) & 0.97 & \pm & 0.17 \\
\hline 0.30 & 6 & 180 & \pm & 52 & (345) & 0.93 & \pm & 0.08 \\
\hline 0.50 & - & 512 & \pm 2 & 31 & (920) & & - & \\
\hline 0.50 & 2 & 512 & & 33 & (926) & 1.06 & \pm & 0.07 \\
\hline 0.50 & 4 & 510 & \pm 2 & 25 & (945) & 1.01 & \pm & 0.03 \\
\hline 0.50 & 6 & 493 & \pm 2 & 20 & (898) & 1.00 & \pm & 0.06 \\
\hline 0.50 & - & 351 & \pm & 13 & (387) & & - & \\
\hline 0.50 & 15 & 414 & \pm & 54 & (415) & 1.18 & \pm & 0.11 \\
\hline 0.50 & 50 & 397 & \pm & 14 & (413) & 1.13 & 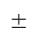 & 0 \\
\hline 0.50 & 100 & 329 & \pm & 49 & (288) & 0.95 & \pm & 0.09 \\
\hline
\end{tabular}

1. Values represent mean of 3 experiments \pm s.d.

2. Mean ratio of experimentally observed $\mathrm{C} / 10^{6} \mathrm{~s}$ values divided by expected values \pm s.d

(Expected values in each set of data are values which are obtained in the absence of IA)

* Values in the parentheses indicate actual colonies counted

typhimurium and $\mathrm{CHO}$ cells. TPA also enhanced the frequency of spontaneous and X-ray induced sister chromatid exchanges in mammalian cells (Kinsella and Radman 1974; Ohno 1974). In addition, our earlier study demonstrated that tumour promoter anthralin enhanced 4-NQO induced mutations in diploid yeast (Anjaria and Rao 2004).

Very little information is available on the cytotoxic and/or potentiating effects of IA. Kiffe et al. (2003) has studied the characterization of cytotoxic and genotoxic effects of different compounds in CHOK5 cells with the comet assay. They observed that IA does not induce direct DNA damage as was reported earlier by others although it induced statistically significant alterations in DNA migration (Hilliard et al. 1998). Even though it was clearly observed that IA induced genotoxic effects in standard comet assay, it did not, however, increase the tail length or moment when lysed cells were used indicating that the compound did not directly damage DNA. 
IA induced low numbers of SCE in V79 cells (Connell and Duncan 1981) and also chromosomal aberrations in $\mathrm{CHO}$ cells which was reported to be due to secondary effects occurring due to its cytotoxicity (Hilliard et al. 1998). However, Kleijer et al. (1973) have reported that IA induced a small number of breaks in the DNA of $\mathrm{T}$ cells and also inhibited rejoining of single strand breaks induced by $\mathrm{X}$-rays by inhibiting enzymes directly.

A few papers have explained the role of IA in the regulatory mechanism of carbohydrate metabolism (Wu and Racker 1958) and also the mechanism by which halogenacetates interact with -SH compounds (Dickens 1933). IA is a classical inhibitor of anaerobic glycolysis, acting primarily on the enzyme glyceraldehyde-3phosphate dehydrogenase which catalyzes the conversion of glyceraldehyde-3-phosphate into the high energy phosphate compound, 1,3 bisphosphoglycerate with the reduction of NAD ${ }^{+}$ to NADH $\left(\mathrm{H}^{+}\right)$(Bickis and Quastel 1965). IA is also reported to be an inhibitor of glucose-6phosphate dehydrogenase (G6PDH) and 6phosphogluconate dehydrogenase, the key enzymes of the oxidative segment of PPP. Addition of IA to ascites tumour cells which were suspended in glucose in air, increased the intracellular concentrations of fructose diphosphate, which accounts for more than 50\% of the consumed glucose ( $\mathrm{Wu}$ and Racker 1958). These observations, however, cannot explain the modifying effects of IA observed in our study wherein IA selectively decreased spontaneous and induced frequency of back mutation and ACF without affecting gene conversion frequency. If inhibition in energy production reported above by others was responsible for observing any inhibition of the induction of genetic events, it would have inhibited all the end-points uniformly, but not just two out of three end-points studied. Fahim et al. (2003) have reported the antitumour activities of IA and Dimethylsulphoxide against solid Ehrlich carcinoma growth in mice. They have reported an increase in the life span and tumour growth inhibition ratio to 145.7 and $63.8 \%$ by IA respectively. However, the biochemical changes responsible for these observations, viz. the inhibition of the main pathways of energy production (glycolysis, pentose monophosphate pathways and glycogenolysis) would also not selectively modify only two of the three genetic end-points studied in this paper, hence these observations too are not relevant for our studies. By the same logic, the mechanism by which halogenacetates interact with -SH compounds (Dickens 1933) cannot explain our results.

The potentiating effects of tumour promoters including IA were studied by Kunz et al. (1980b) using the same yeast system, which we have used. In their study, UV radiation was used as initiating agent. The results indicated that IA was weakly recombinagenic per se at low concentrations but it did not increase UV induced gene conversion. Further it potentiated UV induced back mutation, mitotic crossing over and aberrant colony formation. We have carried out experiments using gamma radiation and 4-NQO as initiating agents in order to understand whether the potentiating effect of IA observed for UV radiation is consistently seen for all the DNA damaging (initiating) agents or is specific for UV radiation. It was observed that IA did not increase spontaneous gene conversion frequency in our experiments, which may be due to lower number of convertant colonies counted in our study. It is to be noted that the increase in background frequency in Kunz's (1980b) study was small and only for low concentrations of IA. We further observed that IA did not increase gamma radiation or 4-NQO induced gene conversion. This observation is similar to the results obtained with UV by Kunz et al. (1980b). However, we also observed that IA reduced the frequencies of two of the three end points studied in the present study, viz., spontaneous and induced back mutation, as well as aberrant colony formation induced by radiation or 4-NQO. These results are in contrast with those observed by Kunz et al. (1980b). These observations also indicated that IA does not reduce the DNA damage induced by gamma radiation and 4-NQO by a general errorfree mechanism affecting all the end-points, but it selectively alters the response of two of the three end points studied, depending upon the mechanisms by which these events are induced. Similar antimutagenic action of some other tumour promoters was reported by Fahrig in yeast (1992, 1995) but in these cases the antimutagenic activity was accompanied by co-recombinagenic activity. Since the modifying effects of IA observed by Kunz (1980b) with UV as initiating agent are not the same as those observed by us with gamma radiation and 4-NQO, it appears that modifying effects of IA depends entirely upon the mechanism 
of action of the initiating agents and also the end point considered.

In conclusion, IA, reported to be a tumour promoter of moderate potency, does not potentiate any genotoxic events induced by gamma radiation and 4-NQO in vitro in yeast in the present study In the absence/scarcity of data pertaining to the tumour promoting ability of iodoacetate in animal systems and also, since most of the studies describe only other characteristics related to its tumour promoting ability, our above observation indicates that extensive studies with IA in combination with various other chemical carcinogens are necessary to understand the mechanism by which IA may bring about its tumour promoting effects in animals and its potentiating effects with respect to genetic events induced in in vitro test systems in order to justify its classification as a tumour promoter of moderate potency.

\section{ACKNOWLEDGEMENTS}

The authors wish to thank Mr. S. Kannan, Head, Radiological Physics \& Advisory Division and Dr. R. K. Kher, Head, Personnel Dosimetry \& Dose Registry Section, for their support and encouragement. Thanks are also due to Mr.U.B. Thorat, Mr.S.C. Jagtap, Mr. P.J. Tondlekar and Mr. S.I. Reddy for the excellent technical assistance.

\section{REFERENCES}

Akaboshi E, Inoue Y, Ryo H 1994. Cloning of the cDNA and genomic DNA that correspond to the recA-like gene of Drosophila melanogaster. Japanese J Genet, 69: $663-670$.

Anjaria KB, Rao BS 2001. Effect of caffeine on the genotoxic effects of gamma radiation and 4-NQO in diploid yeast. J Env Path Toxico Onco, 20: 3945.

Anjaria KB, Rao BS 2004. Effect of Tumour promoter anthralin on gamma radiation and 4-Nitroquinoline 1-oxide induced genotoxicity in diploid yeast. Int $J$ Hum Genet, 4: 243-248.

Bezzubova O, Schmidt H, Ostermann K, Hedder WD, Buerstedde JM 1993. Identification of a chicken RAD52 homologue suggests conservation of the RAD52 recombination pathway throughout the evaluation of higher eukaryotes. Nucleic Acid Res, 21: 5945-5949.

Bickis IJ, Quastel JH 1965.Effects of metabolic inhibitors on energy metabolism of Ehrlich ascites carcinoma cells. Nature, 205: 44-46.

Connell JR, Duncan SJ 1981. The effect of non-phorbol promoters as compared with phorbol myristate acetate on sister chromatid exchange induction in cultured Chinese hamster cells. Cancer Let, 11: 351356.

Cromie GA, Connelly JC, Leach DR 2001. Recombination at double-strand breaks and DNA ends: conserved mechanisms from phage to humans. Mol Cell, 8: 1163-1174.

Deans R, Griffin CS, Maconochie M, Thacker J 2000. $X r c c 2$ is required for genetic stability, embryonic neurogenesis and viability in mice. EMBO J, 19: 6675-6685.

Dickens F 1933. CLII. Interaction of halogenacetates and $\mathrm{SH}$ compounds. The reaction of halogenacetic acids with glutathione and cysteine. The mechanism of Iodoacetate poisoning of glyoxalase. Biochem $J$, 27: 1141-1151.

Dudas A., Chovanec M 2004. DNA double strand repair by homologous recombination. Mutat Res, 566: 131-167.

Essers J., Hendriks RW, Swagemakers SMA, Troelstra C, Dewit J, Bootsma D,. Hoeijmakers JHJ, Kanaar R 1997. Disruption of mouse RAD54 reduces ionizing radiation resistance and homologous recombination. Cell, 89: 195-205.

Fahim FA,Esmat AY, Mady EA, Ibrahim EK 2003. Antitumour activities of iodoacetate and dimethylsulphoxide against solid Ehrlich Carcinoma Growth in mice. Biol Res,. 36: Santilago.

Fahrig R 1975. A mammalian spot test: Induction of genetic alterations in pigment cells of mouse embryos with X-rays and chemical mutagens. Mol. Gen. Genet, 138: 309-314.

Fahrig R 1978. The mammalian spot test, a sensitive in vivo method for the detection of genetic alterations in somatic cells of mice. In: A. Hollander, FJ de Serres (Eds): Chemical Mutagens; Principles and Methods for their Detection, Plenum: New York, pp. 151-176.

Fahrig R 1984. Genetic mode of action of cocarcinogens and tumour promoters in yeast and mice. Mol Gen Genet, 194: 7-14.

Fahrig R 1992. Co-recombinagenic effects. Mutat Res, 284: $185-193$.

Fahrig R 1995. Anti-mutagenic agents are also corecombinagenic and co-mutagenic agents are also anti-recombinagenic. Mutat Res, 326: 245-246.

Gateff E 1978 Malignant neoplasms of genetic origin in Drosophila melanogaster. Science, 200: 1448-1459.

Gentil G, Renault A, Margot A 1980. The effect of the tumour promoter 12-O-tetradecanoyl-phorbol 13acetate(TPA) on UV- and MNNG-induced sister chromatid exchanges in mammalian cells. Int $J$ Cancer, 26: 517-521.

Harris H, Miller OJ, Klein G, Worst P, Tachibana T.1968. Suppression of malignancy by cell fusion. Nature, 223: 363-368.

Hilliard CA, Armstrong MJ, Bradt CI, Hill RB, Greenwood SK, Galloway SM 1998. Chromosome aberrations in vitro related to cytotoxicity of nonmutagenic chemicals and metabolic poissons. Environ Mol Mutagen, 31: 316-326.

Kiffe M, Christen P, Arni P 2003. Characterization of cytotoxic and genotoxic effects of different compounds in $\mathrm{CHO}$ K5 cells with the comet assay (single-cell gel electrophoresis assay). Mutat Res, 537: $151-158$.

Kinsella AR, Radman M 1978. Tumour promoter induces 
sister chromatid exchanges; Relevance to mechanisms of carcinogenesis. Proc, Natl. Acad. Sci (USA), 75: $6149-6158$

Kinsella. AR 1982. Elimination of metabolic cooperation and the induction of sister chromatid exchanges are not properties common to all promoting or co-carcinogenic agents. Carcinogenesis, 3: 499-503.

Kleijer WJ, Hoeksema JI, Sluyter ML, Bootsman D 1973. Effects of inhibitors on repair of DNA in Normal human and Xeroderma pigmentosum cells after exposure to X-rays and ultraviolet irradiation. Mutat Res, 17: 385-94.

Kunz BA, Barclay BJ, Haynes RH 1980a. A simple, rapid, plate assay for mitotic recombination. Mutat Res, 73: 215-220.

Kunz BA, Hannan MA, Haynes RH 1980b. Effect of tumour promoters on UV light-induced mutation and mitotic recombination in Saccharomyces cerevisiae. Cancer Res, 40: 2323-2329.

Lim DS, Hasty RA. 1996 A mutation in mouse rad51 results in an early embryonic lethal that is suppressed by a mutation in p53. Mol Cell Biol, 71: 71337143 .

Luo GB, Yao MS, Bender CF, Mills M, Bladl AR, Bradley A,, Petrini JHJ 1999. Disruption of mRad50 causes embryonic stem cell lethality, abnormal embryonic development and sensitivity to ionizing radiation. Proc Natl Acad Sci (USA), 96: 7376-7381.

McCann J, Choi E, Yamasaki E, Ames BN 1975. Detection of carcinogens as mutagens in the Salmonella/microsome test: Assay of 300 chemicals. Proc Natl Acad Sci (USA), 12: 5135-5139.

McCann J, Ames BN 1976. Detection of carcinogens as mutagens in the Salmonella/microsome test: Assay of 300 chemicals: Discussion. Proc Natl Acad Sci (USA), 73: 950-954.

Miller JA, Miller EC 1971. Chemical carcinogenesis, mechanism and approaches to its control. J Natl Cancer Inst, 47: V-XIV.

Morita T, Yoshimura Y, Yamamoto A, Murata K, Mori M,Yamamoto M, Matsushiro A 1993. A mouse homolog of the Escherichia coli recA and Saccharomyces cerevisiae Rad51 genes. Proc Natl Acad Sci (USA), 90: 6577-6580.

Morrison C, Takeda S 2000. Genetic analysis of homologous DNA recombination in vertebrate somatic cells. Int J Biochem Cell Biol, 32: 817-831.

Ohno S 1974. Aneuploidy as a possible means employed by malignant cells to express recessive phenotypes. In: J. German (Ed.), Chromosomes and Cancer. New York: John Wiley and Sons, Inc. pp.77-94.

Ostermann K, Lorentz A, Schmidt H 1993. The fission yeast $\mathrm{rad} 22$ gene, having a function in switching and repair of DNA damages, encodes a protein homolog to Rad52 of Saccharomyces cerevisiae. Nucleic Acids Research, 21: 5940-5944.

Pittman DL, Schimenti JC 2000. Midgestation lethality in mice deficient for the Rec-A related gene Rad51d/ Rad5113. Genesis, 26: 157-173.

Rijkers T, van den Ouweland J, Morolli B, Rolink AG, Baarends WM, van Sloun PPH, Lohman PHM, Pastink A 1998. Targeted inactivation of mouse $R A D 52$ reduces homologous recombination but not resistance to ionizing radiation. $\mathrm{Mol}$ Cell Biol, 18: 6423-6429

Russell LB, Major MH 1957. Radiation-induced presumed somatic mutations in the house mouse. Genetics, 42: $161-175$.

Shinohara A, Ogawa H, Matsuda Y, Ushio N, Ikeo K, Ogawa T 1993. Cloning of human, mouse and fission yeast recombination genes homologous to RAD51 and recA. Natural Genetics, 4: 239-243.

Shu ZG, Smith S, Wang LJ, Rice MC, Kmiec EB, 1999. Disruption of muREC2/RAD51L1 in mice results in early embryonic lethality which can be partially rescued in a $553 \%$ background. Mol Cell Biol, 19: 8686-8693.

Stanbridge EJ 1976. Suppression of malignancy in human cells. Nature, 260: 17-20.

Sung P, Trujillo KM, Van Komen S 2000. Recombination factors of Saccharomyces cerevisiae. Mutat Res, 451: $257-275$.

Thomson LH 1996. Evidence that mammalian cells possess homologous recombinational repair pathways. Mutat Res, 363: 77-88.

Thomson LH, Schild D 1999. The contribution of homologous recombination in genomic integrity in mammalian cell. Biochimie, 81: 87-105.

Thomson LH, Schild D 2001. Homologous recombinational repair of DNA ensure mammalian chromosome stability. Mutat Res Fundam Mol Mech Mut Res, 477: 131-153

Trosko JE, Chang C, Yotti LP, Chu EHY 1977. Effect of phorbol myristate acetate on the recovery of spontaneous and ultraviolet light-induced 6thioguanine and oubain-resistant Chinese hamster cells. Cancer Res, 37: 188-193.

Tsuzuki T, Fujii Y, Sakumi K, Tominaga Y, Nakao K, Sekiguchi M, Matsushiro A,. Yoshimura Y, Morita T 1996. Targeted disruption of the Rad51 gene leads to lethality in embryonic mice. Proc Natl Acad Sci (USA), 93: 6236-6240.

UNSCEAR 1999. United Nations Scientific Committee on the Effects of Atomic Radiation, Combined Effects of Radiation and Other Agents. Veinna: UNSCEAR

van den Bosch M, Lohman PHM, Pastink A 2002. DNA double-strand break repair by homologous recombination. Biol Chem, 383: 873-892.

Wu R, Racker E 1958. Regulatory mechanisms in carbohydrate metabolism. J Biol Chem, 234: 10291035 .

Yamasaki H 1980. Reversible inhibition of cell differentiation by phorbol esters as a possible mechanism of the promotion step in chemical carcinogenesis. In: R. Montesano, H. Bartsch, L. Tomatis (Eds.): IARC Scientific Publications No.27. Lyon: International Agency for Research on Cancer. pp. 91-111.

Zimmermann FK 1973. A yeast strain for visual screening for the two reciprocal products of mitotic crossing over. Mutat Res, 21: 263-269.

Zimmermann FK 1977. Procedures used in the induction of mitotic recombination and mutation in the yeast Saccharomyces cerevisiae. In: BJ Kilbey, MS Legator, W Nichols, C Ramel (Eds.): Handbook of Mutagenicity Test Procedures. Elsevier: NorthHolland Biomedical Press, pp. 119-134.

Zimmermann FK, Schwaier von Laer U 1966. Mitotic recombination induced in Saccharomyces cerevisiae with nitrous acid, diethyl sulphate and carcinogenic nitrosamides. Z. Vererbungsl, 98: 230-246

Zimmermann FK, Kern R, Rasenberger H 1975. A yeast strain for simultaneous detection of induced mitotic crossing over, mitotic gene conversion and reverse mutation. Mutat Res, 28: 381-388. 